\title{
A Study on Interactive Development of Conference \& Exhibition Industry and Tourism industry of Jilin Province
}

\author{
Lixin li \\ Changchun Vocational Institute of Technology, Changchun Jilin ,130000,China
}

Key words: Conference \& exhibition industry, Tourism industry, Interactive development, Mode.

\begin{abstract}
For purpose of interactive development of conference \& exhibition industry and tourism industry of Jilin province, the integrated development mode and the diversification development mode can be adopted, to promote the perfection and improvement of interactive development of conference \& exhibition industry and tourism industry of Jilin province by establishing a unified management system, integrating related resources, expanding network informationization, developing new products, and exerting brand effect.
\end{abstract}

\section{Development Situation of Conference \& Exhibition Industry of Jilin Province}

The development of conference \& exhibition industry reflects the history of technological and economic development of a country and region. Since we entered the new century, China's conference \& exhibition industry has penetrated into every economic sector, and maintains an annual growth rate of nearly $20 \%$ as a whole. Particularly, as Changchun International Conference \& Exhibition Center was put into use, the conference \& exhibition industry of Jilin province entered a rapid development stage. Large-scale travelling exhibitions from all over the country gather in Changchun, and self-owned brand conference \& exhibition rapidly grow, forming a conference \& exhibition economic system, and having established the status of Jilin in the Northeast China's conference \& exhibition circle. The development situation is as below:

\section{Conference \& exhibition venues with advanced facilities.}

The conference \& exhibition venues in Jilin province include Changchun International Conference \& Exhibition Center, Changchun Agriculture Expo Garden, Jilin Municipal Conference \& Exhibition Center, Yanbian International Conference \& Exhibition Center, etc.. These venues all have a rational structure, are well equipped, and have complete functions, capable of undertaking large-scale international exposition and national conference and exhibition.

\section{Conference \& exhibition scale grows rapidly.}

Since 2010, the conference \& exhibition industry of Jilin province has been taking on a swift growth tendency, realizing an average annual growth rate higher than $20 \%$, and having become one of the most active and potential economic sectors in Jilin province.

\section{Brand conference \& exhibition grow rapidly.}

Through vigorous cultivation in the last years, influential brand conferences and exhibitions emerged one after another in Jilin, such as China-Northeast Asia Expo, China Changchun International Automobile Expo, Changchun Agriculture Expo, Jilin Rime Ice Tourism Festival \& International Fair for Investment and Trade, Jilin Chemical Products \& Chemical Equipment Trade Fair, China Jilin International Root Carving \& Wood Carving Expo, China Tumen River Region International Fair for Investment and Trade, and Yanbian Sino-Russia-South Korea-Singapore Circulation Expo, etc.

\section{Conference \& exhibition forms are innovated and developed.}

The conference \& exhibition industry in Jilin province has formed two distinctive features: combination of regular exhibition with travelling exhibition; connection of exhibition, conference, 
festival, show, sports event. At the time of developing local conference and exhibition, over 20 large-scale professional travelling exhibitions have been successfully held in Jilin, including the Seventh China International Agricultural Trade Fair, the Ninth North China Travel Fair, the Eighth National Book Expo, the Third China Bioindustry Convention, etc.

\section{Good economic benefits of conference \& exhibition are achieved.}

According to incomplete statistics, since 2011, the average annual income of Jilin province directly from the conference \& exhibition industry has reached around RMB1 billion, and the conference \& exhibition industry of Jilin province brought more than RMB10 billion income to relevant industries a year, and stimulated social and economic growth up to ten billion yuan in 2012. According to a sampling survey, during the 9th China-Northeast Asia Expo in September 2013, the number of participants from home and abroad reached over 100, 000, the volume of transaction of foreign commodity trade reached USD840 million, the volume of transaction of domestic commodity trade reached RMB2,25 billion, and more than 500,000 person/time visited the venue.

\section{Development Situation of Tourism Industry of Jilin Province}

In 2013, the total number of tourists and the gross revenue of tourism industry of Jilin approached the national average level and was placed in the middle in the country, having made great contributions to promoting the leapfrog development of economy and society of the province and raising the profile of Jilin province. According to the development state of tourism industry of Jilin province, the trend of second-phase development begins to shape, having basically formed the environment and climate of large-scale development. The development situation of Jilin's tourism industry is as below:

\section{Innovation of system and mechanism is being accelerated.}

Middle and small-sized enterprises are trying to develop themselves into group to enhance their risk resistance capacity. Changbaishan International Resort is a regional tourist project developed by the governments of Baishan municipality and Fusong county, Wanda Group, Asia Standard International Group Limited, Yifang Group, Elion, etc. in the form of cooperation, which is the No.1 foreign-invested project in Jilin province.

\section{Regional tourism traffic becomes more smooth.}

As Changchun Longjia International Airport and Chang Bai Shan International Airport were put into use, and the Hunchun - Changchun line known as the "most beautiful high-speed rail line in Northeast China" was opened, and the regional tourism cooperation process was accelerated, the position of Jilin province in regional tourism sector was further promoted.

\section{Tourism enterprises are striving to develop themselves into groups under specialized operation.}

Most tourism groups in the world are under specialized operation, while those in Jilin province still adopt diversification operation. Specialized operation of tourism enterprise means: firstly, individual travel service developing specialized tourism service or specialized tourism products through market segment; secondly, specialized operation of main business of tourism enterprise group. For individual travel service, specialized operation helps overcome virulent price competition due to homogeneous products, and develop or expand market via differentiation and operation characteristics. 


\section{Interaction Between Conference \& Exhibition Industry and Tourism Industry in Jilin Province}

\section{Benign Interaction Between Conference \& Exhibition Industry and Tourism Industry}

\section{Customer}

Conference \& exhibition generally have a high flow of customer traffic, which provides a large customer base for local tourism. With the constant development of conference \& exhibition industry of Jilin province, the number of participants is increasing, providing a large number of customers for tourism industry.

\section{Earnings}

According to the statistic results of ICCA, the direct influence extent coefficient of conference \& exhibition industry to economic development of developed countries reached 1:5, and the indirect influence extent coefficient reached 1:9. Though China's conference \& exhibition industry started late, the income ratio of tourism, hotel, entertainment, transportation, real estate and advertising indirectly driven by the conference \& exhibition industry has reached 1:6. The participants and related personnel of conference \& exhibition need tourism service, accommodation, and entertainment in the host place, which bring earnings to local tourism industry. Besides, the tourism industry also provides material guarantee for conference \& exhibition.

Quality

Conference \& exhibition industry is a new industry, and requires high-quality cooperation of the tourism industry. On one hand, the tourism industry must give full play to its advantages, and enhance base installation construction to meet the needs of conference \& exhibition; on the other hand, the tourism industry also must raise its quality to keep pace with the new development state of conference \& exhibition. The two industries coordinate with each other to realize benign interaction.

\section{Resource Exchange between Conference \& Exhibition Industry and Tourism Industry}

\section{Information Exchange}

A large amount of information gathers through conference \& exhibition, which brings new thoughts and ideas to the tourism industry. Besides, the introduction of international information also promotes the tourism industry to constantly develop.

\section{Cultural Exchange}

Tourism destination is a place for cultural exchange with the outside. In conference \& exhibition, a large number of foreigners flood in, which stimulates local culture to contact the outside, to enlighten the development of local conference \& exhibition industry.

\section{Scale Effect Relation between Conference \& Exhibition Industry and Tourism Industry}

\section{Construction of Conference \& Exhibition Circle Scale}

Conference \& exhibition circle is an urban economic region of conference \& exhibition industry. At the macro level, it is a union of conference \& exhibition from $\mathrm{N}$ cities; at the micro level, it is a specific activity area suitable for conference \& exhibition development of a city, and the tourism industry of certain scale and grade drives the conference \& exhibition development.

Formation of Service Scale System

Driven by conference \& exhibition development, the tourism competition in the destination becomes increasingly tense, so that a new unified industrial standard is established, and the service system of local tourism industry also is improved day by day, gradually forming a quality service scale system. 
Effect of Interaction between Conference \& Exhibition Industry and Tourism industry of Jilin Province

\section{The conference \& exhibition industry promotes the tourism industry.}

The conference \& exhibition industry provides a large number of customers to the tourism industry. The scale of conference \& exhibition is large, so that a great number of customers are attracted to the host place. Participants in conference \& exhibition are characterized by short residence time, high consumption, and regional restriction, etc., who require much for the services and hardware facilities of tourism. This largely shortens the gap between the off season and peak season of tourism, making up the off-season consumption of tourism and raising the usage rate of base installation and facilities of tourism.

\section{The tourism industry pushes forward the conference \& exhibition industry.}

The development of the conference \& exhibition industry depends on the base installation and hardware facilities of the tourism industry, and that the tourism industry provides complete hardware facilities and equipment to the development of conference \& exhibition is an important basis for the success of conference \& exhibition. The practitioners of tourism are of high quality and can provide good reception services for conference \& exhibition.

\section{Interactive Development of Conference \& Exhibition Industry and Tourism Industry of Jilin Province}

\section{Integrated Development}

Integrated development of conference \& exhibition industry and tourism industry is one of the ways of economic development of Jilin province, which is a new mode developed in combination with the current situation of conference \& exhibition and the characteristics of tourism industry of Jilin province. The Opinions of the State Council on Accelerating the Development of Tourism Industry provides that "we should develop tourism industry as a strategic pillar industry of national economy, vigorously promote the integration of tourism with culture, sports, agriculture, industry, forestry and commerce, and push forward online-offline interaction and integration to drive the development of conference \& exhibition industry and tourism industry."

\section{Diversification Development}

With the development tendency of economic globalization and the acceleration of China's internationalization, the conference \& exhibition industry and tourism industry of Jilin province has become the pillar industry in the tertiary industry. Their industrial chain has been extended, their driving ability has been enhanced, and their comprehensive efficiency and economic benefits have been raised, promoting the industrial structure of Jilin province to optimize and upgrade.

\section{Measures for Promoting Interactive Development of Conference \& Exhibition Industry and Tourism Industry of Jilin Province}

\section{We should establish a unified management system.}

We should promote unified management, standardize the industrial order, and promote the industrial competitiveness. Presently, no unified trade management department of conference \& exhibition industry and tourism industry is established in Jilin. To realize interactive development of the two industries, a management system of conference \& exhibition industry and tourism industry must be established as soon as possible. Considering the conditions of Jilin, the aforementioned management system must be capable of organizing and coordinating conference \& exhibition industry and tourism industry, enhancing the management and communication between conference \& exhibition industry and tourism industry and between the two industries and other industries, and guiding the operation of 
conference \& exhibition industry and tourism industry, to provide a platform for rational and effective interactive development of the two industries.

\section{We should integrate relevant resources.}

Based on the basic conditions of regions in Jilin province, initiating the mode of interactive development of conference \& exhibition industry and tourism industry, giving full play to the superior advantages of conference \& exhibition industry and tourism industry, enhancing the deep integration of conference \& exhibition industry and tourism industry, and integrating resources of conference \& exhibition, tourism, communication, telecommunication, network, entertainment, and transportation to raise development quality and benefits are helpful for advantage complement and resource sharing among industries, stimulating economic growth, and promoting the upgrading and transformation of conference \& exhibition industry and tourism industry.

\section{We should expand network informationization.}

With the advent of internationalization trend of conference \& exhibition industry and tourism industry of Jilin province, we must expand network informationization to create more cooperation opportunities between the two industries, to facilitate various information resource groups such as intermediate agencies of conference \& exhibition and tourism, tourism e-commerce website, industry association data, enterprise information presentation via the internet, journals and magazines so that the conference \& exhibition industry and the tourism industry can get to know each other, and seek cooperation, and information communication between the two industries via online reservation system, telephone and fax be promoted, and the interactive development of the conference \& exhibition industry and the tourism industry be enhanced.

\section{We should develop new-type products.}

According to the individual needs of customers, the development of new-type products should conform to the principle of "Having what others don't have, and innovating the existing". Conference \& exhibition industry, a new-type industry, raises higher requirements for the tourism industry which provide services to it for its large information flow and visitor flow, and the tourism industry should develop high-end tourism products besides meeting the primary needs of participants of conference \& exhibition, to guarantee the mutual development of conference \& exhibition industry and tourism industry.

\section{We should exert brand effect.}

If the brand effect is fully exerted, we can yield twice the result with half the effort. Once a brand becomes distinguishing, of conference \& exhibition or of tourism, huge economic benefits and social benefits come. For example, the continued success of China-Northeast Asia Expo is based on its interaction with Chang Bai Shan Tourist Attraction-the most famous 5A scenic area in Jilin province. The brand advantages of China-Northeast Asia Expo and the scenery advantages of Chang Bai Shan Tourist Attraction are made full use of to attract tourists, to realize interactive development, promote the upgrading and transformation of tourism industry and conference \& exhibition industry, and drive the economic development of Jilin province.

To sum up, the interactive development of conference \& exhibition industry and tourism industry of Jilin province is bound to be realized, improved and developed by establishing a unified management system, integrating relevant resources, expanding network informationization, developing new-type products, exerting brand effect in the mode of integrated development and diversification development, to promote the economic growth of Jilin province.

\section{Acknowledgement}

A Project under the 2015 "Twelfth Five-year Plan" of Science and Technology and Social Sciences Research Program of The Education Department of Jilin Province: A Study on Interactive 
Development of Conference \& Exhibition Industry and Tourism industry of Jilin Province (Ji Jiao Ke Wen He Zi [2015] No. 468)

\section{References}

[1] Lyu Tao, Nie Rui, Theoretical Basis and Manifestation of Connotation of Industry Linkage Development, Journal of Industrial Technological Economics, 2007.05

[2] Shen Zhengping, Jian Xiaobin, Shi Tongbing, Discussions on Measure Methods and Application of Regional Industry Linkage Development, Economic Geography, 2007.06

[3] Liu Zhao, A Study on Regional Harmonious Economic Development Mechanism based on Industry Linkage Development, Research of Finance and Accounting, 2009.01

[4] Yu Xiangping, Structure and Industry Extension Effect of Conference \& Exhibition Industry Chain, Commercial Research, 2008.08

[5] A Study on Interactive Development of Conference \& Exhibition Industry and Tourism Industry, China's Conference \& Exhibition Research Center, 2010.01.14

[6] Zhao Deyin, Wei Youguang. Exploration into Linkage Development of Conference \& Exhibition Industry and Tourism Industry of China under the Context of Industry Integration, Ecological Economy (Academic Edition), 2010.2

[7] Wei Zhongjing. Discussions on Connection between Conference \& Exhibition Industry and Tourism Industry, Southeast University. 2006.

[8] Guo Man, Fu Yunxin. Discussions on Interactive Development of Conference \& Exhibition and Travel Agency, Journal of Guilin Institute of Tourism. 2006 (3).

[9] Xiao Hongyan, Discussions on Interactive Relationship between and Development Mode of Conference \& Exhibition Industry and Tourism Industry, Economic Forum, 2009. 23.

[10]Conference \& exhibition and tourism drive each other.

[11]2010-2015 China's Tourism Industry Investment Analysis and Prospect Forecast Report www.ocn.com.cn.

[12] Guiding Opinions of the Ministry of Commerce on Promoting the Development of Conference \& Exhibition Industry during the "Twelfth Five-year Period" .

[13]Suggestions of the CPC Jilin Provincial Committee on Making the Twelfth Five-year Plan of Economic and Social Development of Jilin Province.

[14]Layout of the Twelfth Five-year Plan of Economic and Social Development of Jilin Province.

[15] Suggestions of the CPC Jilin Provincial Committee on Making the Thirteenth Five-year Plan of Economic and Social Development of Jilin Province.

[16] Implementation Suggestions of Jilin Provincial People's Government General Office on Accelerating the Reform and Development of Exhibition Industry of Jilin Province.

[17] Opinions of the State Council on Accelerating the Development of Tourism Industry.

[18] Several Opinions of the State Council on Further Promoting the Reform and Development of the Exhibition Industry. 